troublesome and fibrillation may afford an additional layer of protection and allow more effective deairing in some cases. Additional benefits from fibrillating the heart during pump exchange are reduced blood loss from the apical inflow site during pump exchange and decreased risk of blood contact contamination of the operating team from an ejecting left ventricle. Because most patients with an LVAD also have an AICD in situ, we suggest that the method described here is a simple means to induce, maintain, and reverse fibrillation. Although dissecting out the base of the right ventricle to attach a fibrillator lead is also possible, this adds another layer of complexity to the surgery with increased risk of bleeding and injury to the heart, and risks unanticipated cardiac ejection if wires are displaced and the heart beats spontaneously. By using the AICD to fibrillate, we were able to keep the procedure almost entirely within the LVAD pocket, making it truly minimally invasive. Furthermore, as seen in our case, defibrillation by external pads may be difficult.
The potential applications of this approach are not limited to LVAD device exchange, but could be extended to other minimal access cardiac surgical procedures in patients who have AICDs. The approach may be useful in such procedures, particularly where access to the heart is limited, or where there is a desire to avoid aortic clamping, such as mitral valve repair via thoracotomy in a patient with previous coronary bypass grafts and depressed ventricular function.

\section{References}

1. Birks EJ. A changing trend toward destination therapy. Tex Heart Inst J. 2011;38: $552-4$

2. Park SJ, Tector A, Piccioni W, Raines E, Gelijns A, Moskowitz A, et al. Left ventricular assist devices as destination therapy: a new look at survival. $J$ Thorac Cardiovasc Surg. 2005;129:9-17.

3. Moazami N, Milano CA, John R, Sun B, Adamson RM, Pagani FD, et al. Pump replacement for left ventricular assist device failure can be done safely and is associated with low mortality. Ann Thorac Surg. 2013;95:500-5.

4. Woo YJ, Acker MA. Implantable ventricular assist device exchange with focused intravascular deairing techniques. Ann Thorac Surg. 2011;91:306-7.

\title{
Cardiac hemangioma at the apex of the right ventricle: A case report and literature review
}

\author{
Wen-Jian Jiang, MD, Jin-Hua Li, MD, Jiang Dai, MD, and Yong-Qiang Lai, MD, Beijing, China
}

Primary tumors and cysts of the heart and pericardium are rare, and only $2.8 \%$ of these tumors are cardiac hemangiomas. ${ }^{1}$ Ventricular hemangiomas are extremely uncommon. We report one of these unusual cases and discuss others in the literature.

\section{CLINICAL SUMMARY}

A 49-year-old man without symptoms was admitted to our hospital. A mass between the right ventricle (RV) and the pericardium was demonstrated on his chest computed tomography (Figure 1, A). Transthoracic echocardiography showed the mass to be located at the apex of the RV, and there was no hemodynamic abnormality or RV outflow tract obstruction.

From the Department of Cardiac Surgery, Beijing Anzhen Hospital, Capital Medical University, Beijing, China.

Disclosures: Authors have nothing to disclose with regard to commercial support.

Received for publication Oct 13, 2013; accepted for publication Oct 31, 2013; available ahead of print Dec 2, 2013.

Address for reprints: Yong-Qiang Lai, MD, Department of Cardiac Surgery, Beijing Anzhen Hospital, Beijing 100029, China (E-mail: yongqianglai@yahoo.com).

J Thorac Cardiovasc Surg 2014;147:e18-21

$0022-5223 / \$ 36.00$

Copyright (c) 2014 by The American Association for Thoracic Surgery

http://dx.doi.org/10.1016/j.jtcvs.2013.10.046
The mass adjacent to the RV had a clear border with the normal myocardium (Figure 1, B). It was totally excised under cardiopulmonary bypass. A patch of autologous pericardium covered with Dacron polyester fabric was used for the reconstruction of the RV (Figure 1, C). This patient recovered uneventfully, with no evidence of recurrence after 6 months of follow-up. The size of the mass was $6.8 \times 5.0 \times 2.6 \mathrm{~cm}($ Figure $1, D)$. Histologic diagnosis was hemangioma (Figure 1,E).

\section{DISCUSSION}

Primary tumors and cysts of the heart and pericardium are rare, and only $2.8 \%$ of these tumors are cardiac hemangiomas. ${ }^{1}$ Hemangiomas of the heart affect all ages and may occur anywhere within the heart, ${ }^{2}$ but ventricular hemangiomas are extremely uncommon. In 45 reviewed cases of cardiac hemangioma, only 11 were located in the RV. ${ }^{3}$ Cardiac hemangiomas are vascular tumors composed of capillaries or cavernous vascular channels, and most are benign. ${ }^{4}$ Surgery is the first choice of therapy in all patients with cardiac tumors. ${ }^{5}$

To date, 30 cases of hemangiomas located in the RV (including that reported here) have been reported in the literature. Table 1 shows the summary of preoperative data and lists the surgical procedures in these cases. The 


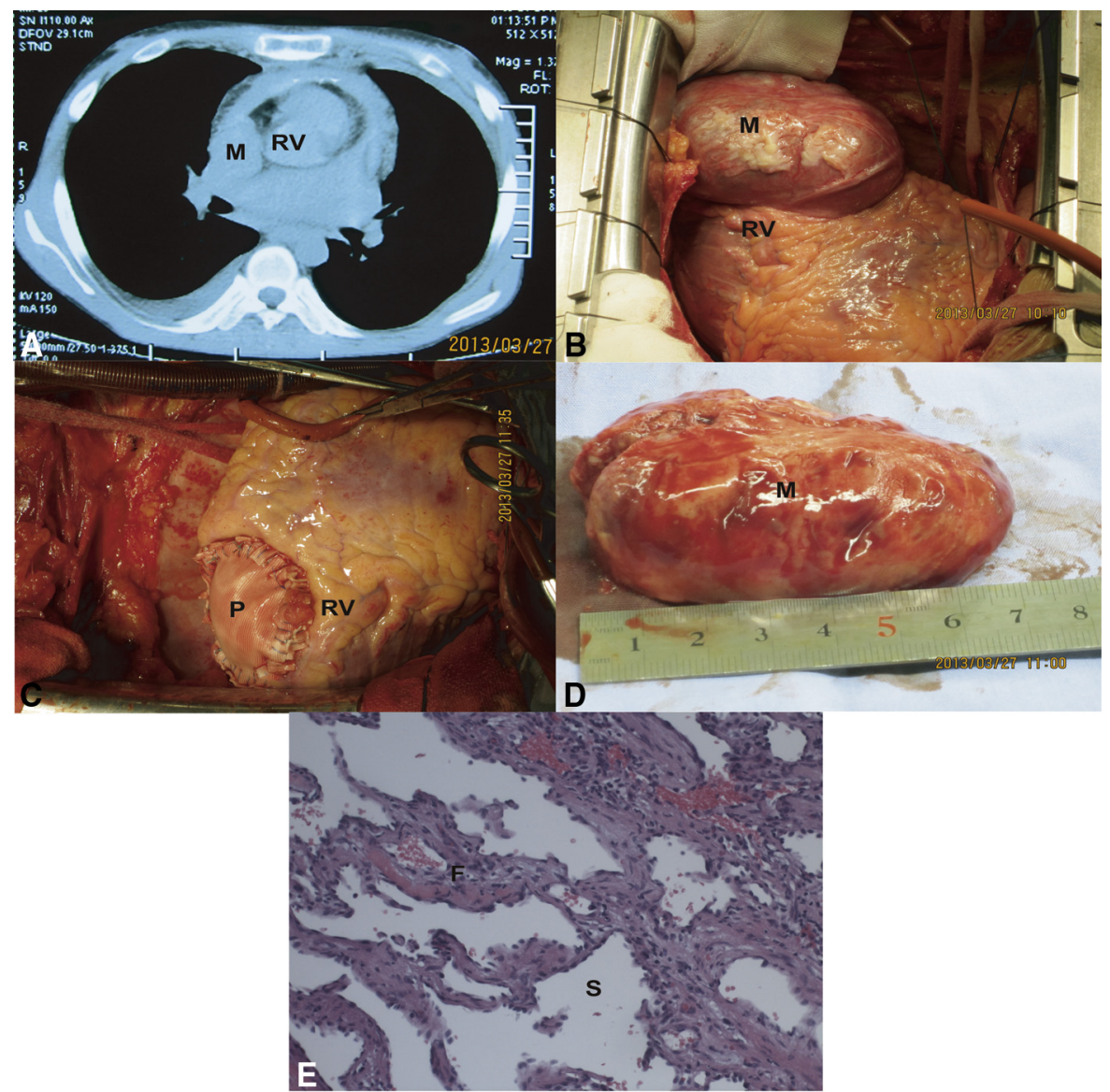

FIGURE 1. A, Computed tomographic view shows a tumor mass $(M)$ in the right ventricle $(R V)$. B, After sternotomy, the tumor can be seen in the apex of the right ventricle. $\mathrm{C}$, Operative photograph shows the reconstruction of the right ventricle after the resection of the tumor with a graft patch $(P)$. $\mathrm{D}$, Photograph shows a macroscopic view of the tumor, which was $6.8 \times 5.0 \times 2.6 \mathrm{~cm}$. E, Photomicrograph shows a microscopic view of the tumor (original magnification $\times 200$ ). $F$, Fiber trabecular; $S$, sinusoids.

most common sites were the anterior wall of the RV in 20 patients $(66.7 \%)$, including the apex of the RV in 2 patients and the RV outflow tract in 10 others $(33.3 \%)$. Sotoda and colleagues ${ }^{6}$ reported the first cardiac hemangioma at the apex of the RV in 2008, and our case is the second ever reported.

All 30 patients described in the literature underwent operation. Cardiopulmonary bypass was used in $76.7 \%$ of the cases. Total resection of the tumor was done in $83.3 \%$ of cases, $88 \%$ with cardiopulmonary bypass. Surgical outcome and follow-up information were available for 23 patients, who were followed up for periods ranging between 6 months and 2 years; all were alive and well at follow-up. Especially for the cardiac hemangiomas located in the anterior wall of the RV, the reconstruction of cardiac ventricle after the resection of the tumor, which is the same as the procedure after the resection of ventricular aneurysmectomy, is important, because heart failure can result from low cardiac output. ${ }^{5}$ Because of the reconstruction of the $\mathrm{RV}$, postoperatively cardiac function in our case was satisfactory.
Considering all the points discussed here, we may safely conclude that most cardiac hemangiomas in the RV are located in the anterior wall, and these patients should undergo reconstruction of the ventricle after resection of the tumor under CPB. Long-term outcome seems satisfactory, and little recurrence has been reported.

\section{References}

1. McAllister H. Tumors of the heart and pericardium. In: Silver MD ed. Cardiovascular pathology. New York: Churchill Livingstone; 1983: 909-43.

2. Brizard C, Latremouille C, Jebara VA, Acar C, Fabiani JN, Deloche A, et al Cardiac hemangiomas. Ann Thorac Surg. 1993;56:390-4.

3. Burke A, Virmani R. Atlas of tumor pathology. Tumors of the heart and great vessels. 3rd series, fascicle 16. Washington, DC: Armed Forces Institute of Pathology; 1995:80-6.

4. Van Trigt P III, Sabiston DC Jr. Tumors of the heart. In: Sabiston DC, Spencer FC eds. Surgery of the chest, vol. 2. 6th ed. Philadelphia: WB Saunders; 1995: 2069-86.

5. Colli A, Budillon AM, DeCicco G, Agostinelli A, Nicolini F, Tzialtas D, et al Recurrence of a right ventricular hemangioma. J Thorac Cardiovasc Surg. 2003; 126:881-3.

6. Sotoda Y, Hirooka S, Kohi M, Orita H, Mori M. Intramuscular hemangioma in the right ventricle. Gen Thorac Cardiovasc Surg. 2008;56:85-7. 
TABLE 1. Summary of preoperative data and details of surgical procedures in 30 cases of right ventricular hemangioma reported in the literature

\begin{tabular}{|c|c|c|c|c|c|c|c|c|c|c|}
\hline Case & $\begin{array}{l}\text { First author } \\
\text { and year }\end{array}$ & $\begin{array}{l}\text { Age } \\
(y)\end{array}$ & Sex & $\begin{array}{c}\text { Clinical } \\
\text { presentation }\end{array}$ & $\begin{array}{l}\text { Surgical } \\
\text { access }\end{array}$ & Tumor site & CPB & $\begin{array}{l}\text { Surgical } \\
\text { procedure }\end{array}$ & Outcome & Pathology \\
\hline 1 & Hochberg 1950 & 8 & $\mathrm{~F}$ & Dyspnea & Thoracotomy & $\begin{array}{l}\mathrm{RV} \text { anterior wall, } \\
\text { pericardial pleura }\end{array}$ & $\mathrm{N}$ & Total excision & NA & Cardiac hemangioma \\
\hline 2 & Nicks 1964 & 20 & $\mathrm{~F}$ & $\begin{array}{l}\text { Dyspnea, } \\
\text { murmur }\end{array}$ & Sternotomy & $\begin{array}{l}\mathrm{RV} \text { anterior wall, } \\
\mathrm{RA} \text { anterior wall }\end{array}$ & $\mathrm{Y}$ & Total excision & NA & Vascular hemangioma \\
\hline 3 & $\begin{array}{c}\text { Warembourg } \\
1971\end{array}$ & 44 & $\mathrm{~F}$ & $\begin{array}{l}\text { Dyspnea, } \\
\text { murmur }\end{array}$ & Thoracotomy & RV anterior wall & $\mathrm{N}$ & Total excision & NA & Cardiac hemangioma \\
\hline 4 & Delaye 1972 & 23 & M & Dyspnea & Sternotomy & RVOT & $\mathrm{Y}$ & Total excision & NA & Hemangioendothelioma \\
\hline 5 & Contamin 1973 & 20 & $\mathrm{~F}$ & RH failure & Sternotomy & RV-LV-RA & $\mathrm{N}$ & $\begin{array}{l}\text { No resection, } \\
\text { biopsy }\end{array}$ & NA & Cardiac hemangioma \\
\hline 6 & Thompson 1977 & 10 & $\mathrm{~F}$ & $\begin{array}{l}\text { RH failure, } \\
\text { murmur }\end{array}$ & Sternotomy & RV-LV-PA & $\mathrm{N}$ & $\begin{array}{l}\text { No resection, } \\
\text { biopsy }\end{array}$ & NA & Cardiac hemangioma \\
\hline 7 & Larrieu 1982 & 27 & $\mathrm{~F}$ & $\begin{array}{l}\text { Dyspnea, } \\
\text { murmur }\end{array}$ & Sternotomy & $\begin{array}{c}\text { RV anterior wall, } \\
\text { RA }\end{array}$ & $\mathrm{N}$ & Total excision & Alive and well & Cardiac hemangioma \\
\hline 8 & Novitzky 1984 & 59 & $\mathrm{~F}$ & Pseudoangina & Sternotomy & RVOT & Y & Total excision & Alive and well & Cardiac hemangioma \\
\hline 9 & Palmer 1986 & 43 & M & Arrhythmias & Thoracotomy & $\begin{array}{c}\text { RV anterior wall, } \\
\text { Ao-PA }\end{array}$ & $\mathrm{N}$ & $\begin{array}{l}\text { No resection, } \\
\text { biopsy }\end{array}$ & $\begin{array}{c}\text { Alive and well, } \\
2 \mathrm{y}\end{array}$ & Cardiac hemangioma \\
\hline 10 & Soberman 1988 & 3 & M & Murmur & Sternotomy & RVOT, septum & Y & Partial excision & $\begin{array}{c}\text { Alive and well, } \\
1 \mathrm{y}\end{array}$ & Cardiac hemangioma \\
\hline 11 & $\begin{array}{l}\text { Matsutani T } \\
1989\end{array}$ & 62 & M & RH failure & Sternotomy & RV anterior wall & Y & Total excision & Alive and well & Cardiac hemangioma \\
\hline 12 & $\begin{array}{l}\text { Golosovskaia } \\
1990\end{array}$ & 17 & M & $\begin{array}{l}\text { Dyspnea, } \\
\text { murmur }\end{array}$ & Sternotomy & RV ant wall, septum & $\mathrm{Y}$ & Total excision & Alive and well & Cardiac hemangioma \\
\hline 13 & Liao WH 1990 & 57 & M & $\begin{array}{l}\text { Dull } \\
\text { chest pain }\end{array}$ & Sternotomy & RVOT & $\mathrm{Y}$ & Total excision & $\begin{array}{c}\text { Alive and well, } \\
7 \mathrm{mo}\end{array}$ & Cardiac hemangioma \\
\hline 14 & Reiss N 1991 & 28 & $\mathrm{~F}$ & $\begin{array}{l}\text { Dyspnea, } \\
\text { murmur }\end{array}$ & Sternotomy & RVOT & Y & Total excision & Alive and well & Cardiac hemangioma \\
\hline 15 & $\begin{array}{l}\text { Cunningham } \\
1993\end{array}$ & 17 & M & $\begin{array}{l}\text { Dyspnea, } \\
\text { murmur }\end{array}$ & Sternotomy & RV anterior wall & Y & Total excision & Alive and well & Cardiac hemangioma \\
\hline 16 & Ando M 1993 & 52 & M & NA & Sternotomy & $\begin{array}{c}\text { RV anterior wall, } \\
\text { septum }\end{array}$ & Y & Total excision & Alive and well & Cardiac hemangioma \\
\hline 17 & Brizard 1993 & 24 & M & $\begin{array}{l}\text { Dyspnea, } \\
\text { hepatalgia }\end{array}$ & Sternotomy & RVOT, septum & Y & Total excision & $\begin{array}{c}\text { Alive and well, } \\
1 \mathrm{y}\end{array}$ & Cardiac hemangioma \\
\hline 18 & Gaires 1997 & 36 & $\mathrm{M}$ & NA & Sternotomy & RV anterior wall & $\mathrm{Y}$ & Total excision & Alive and well & Cardiac hemangioma \\
\hline 19 & Harada 1998 & 74 & M & $\begin{array}{l}\text { Dyspnea, } \\
\text { murmur }\end{array}$ & Sternotomy & $\begin{array}{c}\text { RV anterior wall, } \\
\text { septum }\end{array}$ & Y & Total excision & Alive and well & Cardiac hemangioma \\
\hline 20 & Kipfer 2000 & 74 & M & NA & Sternotomy & RV anterior wall & $\mathrm{Y}$ & Total excision & $\begin{array}{l}\text { Alive and well, } \\
12 \mathrm{mo}\end{array}$ & Cardiac hemangioma \\
\hline 21 & Ikeda 2001 & 56 & M & NA & Sternotomy & $\mathrm{RV}$ anterior wall & Y & Total excision & Alive and well & Cardiac hemangioma \\
\hline 22 & Colli 2003 & 69 & M & NA & Sternotomy & RVOT & Y & Total excision & $\begin{array}{l}\text { Alive and well, } \\
6 \mathrm{mo}\end{array}$ & Relapsed hemangioma \\
\hline 23 & Arjomand 2004 & 61 & $\mathrm{~F}$ & $\begin{array}{c}\text { RH failure, } \\
\text { dyspnea }\end{array}$ & Sternotomy & $\mathrm{RV}$ anterior wall & Y & Total excision & Alive and well & Cardiac hemangioma \\
\hline 24 & Iba 2005 & 46 & $\mathrm{~F}$ & Dizziness & Sternotomy & RVOT & Y & Total excision & Alive and well & Cardiac hemangioma \\
\hline 25 & Turkoz 2005 & 61 & $\mathrm{~F}$ & $\begin{array}{l}\text { Palpitation } \\
\text { and } \\
\text { tightness } \\
\text { of chest }\end{array}$ & Sternotomy & $\begin{array}{c}\text { RV anterior wall, } \\
\text { RA }\end{array}$ & $\mathrm{Y}$ & Total excision & $\begin{array}{l}\text { Alive and well, } \\
14 \text { mo }\end{array}$ & Cardiac hemangioma \\
\hline 26 & Sotoda 2008 & 74 & $\mathrm{M}$ & NA & Sternotomy & Apex of RV & Y & Total excision & $\begin{array}{c}\text { Alive and well, } \\
24 \mathrm{mo}\end{array}$ & Cardiac hemangioma \\
\hline 27 & Botha 2010 & 65 & $\mathrm{~F}$ & $\begin{array}{l}\text { RH failure, } \\
\text { murmur }\end{array}$ & Sternotomy & RV anterior wall & $\mathrm{N}$ & $\begin{array}{l}\text { No resection, } \\
\text { biopsy }\end{array}$ & NA & Cardiac hemangioma \\
\hline 28 & Chen 2012 & 42 & $\mathrm{~F}$ & $\begin{array}{c}\text { Chest pain, } \\
\text { edema }\end{array}$ & Sternotomy & RVOT & $\mathrm{Y}$ & Total excision & Alive and well & Cardiac hemangioma \\
\hline
\end{tabular}


TABLE 1. Continued

\begin{tabular}{lccccccccc}
\hline Case & $\begin{array}{c}\text { First author } \\
\text { and year }\end{array}$ & $\begin{array}{c}\text { Age } \\
(\mathbf{y})\end{array}$ & $\begin{array}{c}\text { Sex } \\
\text { presentation }\end{array}$ & $\begin{array}{c}\text { Clinical } \\
\text { access }\end{array}$ & Tumor site & CPB & $\begin{array}{c}\text { Surgical } \\
\text { procedure }\end{array}$ & Outcome & Pathology \\
\hline 29 & Sogawa 2012 & 73 & M & NA & Sternotomy & RVOT & Y & Total excision & Alive and well, Cardiac hemangioma \\
30 & Jiang 2013 & 49 & M & NA & Sternotomy & Apex of RV & Y & Total excision & $\begin{array}{c}\text { Alive and well, Cardiac hemangioma } \\
6 \text { mo }\end{array}$
\end{tabular}

$C P B$, Cardiopulmonary bypass; $F$, female; $R V$, right ventricle; $N A$, not available; $R A$, right atrium; $M$, male; $R V O T$, right ventricular outflow tract; $R H$, right heart; $L V$, left ventricle; $P A$, pulmonary artery; $A o$, aorta.

\title{
Functioning Cooley-Cutter aortic valve prosthesis 40 years after implantation
}

\author{
Sahar A. Saddoughi, ${ }^{a}$ Daniel H. Steinberg, MD, ${ }^{\mathrm{b}}$ and John S. Ikonomidis, MD, PhD, ${ }^{\mathrm{a}}$ Charleston, SC
}

Video clip is available online.

The development of artificial heart valves has revolutionized cardiac surgery. During the past 60 years, heart valve prostheses have evolved considerably, with each new model designed with the hope of better hemodynamics and outcomes for patients. The Cooley-Cutter heart valve was designed in the 1960s by Denton A. Cooley, MD, in collaboration with Cutter Laboratories and introduced for clinical use in 1971. ${ }^{1}$ The device used 2 sets of titanium struts to contain a biconic occluder composed of pyrolytic carbon. Cooley-Cutter heart valves were used frequently in the $1970 \mathrm{~s},{ }^{2}$ with Dr Cooley alone having implanted the device in a total of 3275 patients (1786 in the aortic position and 1475 in the mitral) over a 10-year period, with very good clinical results. ${ }^{3}$ Since that time, newer mechanical valves have replaced the Cooley-Cutter valve.

\section{CLINICAL SUMMARY}

An 85-year-old man with a medical history significant for diabetes, coronary artery disease, previous stent placement

\footnotetext{
From the Division of Cardiothoracic Surgery, ${ }^{\mathrm{a}}$ and the Department of Cardiology, ${ }^{\mathrm{b}}$ Medical University of South Carolina, Charleston, SC.

Disclosures: Authors have nothing to disclose with regard to commercial support.

Received for publication Oct 18, 2013; accepted for publication Oct 28, 2013; available ahead of print Dec 2, 2013.

Address for reprints: John S. Ikonomidis, MD, PhD, Division of Cardiothoracic Surgery, Medical University of South Carolina, Suite 7030, 25 Courtney Dr,

Charleston, SC 29425-2950 (E-mail: ikonomij@musc.edu).

J Thorac Cardiovasc Surg 2014;147:e21-2

$0022-5223 / \$ 36.00$

Copyright (C) 2014 by The American Association for Thoracic Surgery

http://dx.doi.org/10.1016/j.jtcvs.2013.10.068
}

in the left anterior descending coronary artery, and previous mechanical aortic valve replacement was seen for dyspnea on exertion and minor weight loss. The patient's surgical history was significant for aortic valve replacement with a Cooley-Cutter prosthesis, implanted by Dr Cooley at the Texas Heart Institute on October 4, 1973. Results of physical examination were unremarkable; cardiac examination revealed regular rate and rhythm with $\mathrm{S} 1$ and $\mathrm{S} 2$, no S3 or S4, and no appreciable murmurs, rubs, or gallops.

Transthoracic echocardiography (Figure 1) showed an intact aortic valve replacement. The valve was properly seated with normal occluder motion. The peak transvalvular velocity was $3.4 \mathrm{~m} / \mathrm{s}$, with a mean gradient of $24 \mathrm{~mm} \mathrm{Hg}$. The left ventricular ejection fraction was calculated to be $60 \%$.

\section{DISCUSSION}

A recent single-center retrospective review of the results of the use of the St Jude mechanical valve $e^{4}$ demonstrated a 25 -year survival of $17 \% \pm 4 \%$. In the context of these results, it is high unusual to document such excellent functional results as those of this 40-year-old Cooley-Cutter prosthesis. Another mechanical aortic valve prosthesis that has been shown to be remarkably durable in certain cases is the Starr-Edwards prosthesis. ${ }^{5}$ Our patient's symptoms were ultimately found to be unrelated to his cardiac history, and he currently remains well controlled on warfarin. Overall, the prosthetic valve remains in excellent condition with no need for replacement.

\footnotetext{
References

1. Roe BB. "Extinct" cardiac valve prostheses. In: Bodnar E, Frater R, eds Replacement cardiac valves. New York: Pergamon Press; 1991:307-32.
} 